\title{
Selected Concepts in The Development of Drawing Activity in Children Aged 3 to 12
}

\author{
Bernadeta Didkowska \\ Nicolaus Copernicus University in Toruń, Poland \\ E-mail address: bedid@poczta.onet.pl
}

\section{ARTICLE INFO}

\section{Keywords:}

Drawing activity

Children

Development

\section{Article history:}

Received 28 February 2016

Received in revised form 1 September 2016

Accepted 2 September 2016

ISSN: 2354-0036

DOI: $10.1515 /$ ctra-2017-0003

\section{A B S T R A C T}

More than a hundred years of research on the drawing activity of children and young people shows both a change in the way it is perceived and in its importance for healthy development. Numerous monographs, dissertations, research conducted by psychologists, pedagogues, aestheticians, art historians and visual artists has contributed to the popularity of terms such as "children's art" or "children's artistic work". Children's and young people's drawings have not only been acknowledged for their artistic and aesthetic value, but also for their projective and psychometric qualities. Research on children's drawing shows that the depiction is a result of knowledge and perception, which depends on personality and intelligence, as well as on emotions, persistent views and attitudes. Furthermore, the content, as well as the formal qualities of a drawing are subject to the constant influence of changing aesthetic conventions and cultural processes. This article deals with selected classic concepts of artistic development in children aged 3 to 12 defined by researchers such as Stefan Szuman, Georges Henri Luquet, Viktor Lowenfeld and Lambert Brittain, Rudolf Arnheim, Ernst H. Gombrich and Władysław Strzemiński. The crucial aspect of this disquisition was to emphasize the value of spontaneous children's drawings and of the role of spontaneous drawing in their appropriate development. It was equally important to highlight the need for the students to do their own creative work with a teacher assisting them only as a guide, a discrete observer and potential advisor. This is why I pondered upon the following key notions in characterizing the drawing activity of children aged 3 to 12: the period of scheme in drawing development (ideoplastic art, S.Szuman), spontaneous drawing and drawing scheme. 


\section{INTRODUCTION}

Drawing is one of the basic forms of human activity, as it reflects cognitive development. Children's drawings are an important aspect of research on human creative activity, since they reflect psychic processes, knowledge and experience acquired in life.

Drawing is one of the interesting ways in which a child communicates. The drawing reflects what the child thinks and dreams of, wishes to achieve and experience. The drawing is a reflection of the child's fantasy and of the will to act. (Rysowanie jest jedną z ciekawych form wypowiadania się dziecka. W rysunku ukazuje to, o czym myśli i marzy, co pragnie osiągnąć i przeżyć. Rysunek jest wyrazem jego fantazji i chęci działania.) (Hornowski, 1982, p.76).

Drawing allows a child to initiate a relation with the environment, and as this activity develops, to expand the worldview and to include new elements in it, to gain knowledge, to awaken curiosity. Drawing activity is driven by an intrinsic imperative urging the child through drawing - to observe, to express feelings and emotions and to draw satisfaction from it, before reaching the next phase, the artistic crisis.

I believe that children's drawing activity plays an important role in their development, therefore in this article I will discuss particular, classic conceptions of drawing development in children aged 3 to 12, presented by authors who focused on the analysis of artistic development mechanisms and emphasized the value of the student's individual effort. I have also chosen these authors because their theories have explained crucial factors in children's artistic activity development, such as: the period of scheme in drawing development (ideoplastyka), spontaneous drawing, drawing scheme. Since children's artistic activity was characterized on the basis of a body of diverse literature where several aspects of their drawings were described: aesthetic, psychometric, projective - these notions are often imprecise. Therefore it is important, at least briefly, to recapitulate their original meaning.

\section{RESEARCH REVIEW}

A comprehensive review of research on this topic was presented by Hornowski (1982) and Popek (1978). Over a hundred years of research on children and young people have made it clear how much the way of perceiving their drawing activities has changed and how important it is in human development. Numerous monographic scientific studies, studies conducted by psychologists, pedagogues, theoreticians of aesthetics, art historians, artists have all contributed to acknowledging the fact that children's artistic activity is a kind of art, and have made terms such as children's art and children's artistic creativity popular (e.g. Cooke,1885; Ricci, 1887; Grudzińska 1913, Luquet, 1927; Szuman, 1927 / 1990, 
1969; Lowenfeld, \& Brittain, 1947 / 1977; Lam, 1960, 1967; Kellogg,1970; Trojanowska, 1975, 1988; Gaitskel, \& Hurwitz, 1975; Kościelecki 1975, Marciniak 1976, Popek, 1978, 1988, 2010; Winner, 1982; Malraux, 1985; Wallon i in., 1993; Limont, 1994, 1996, 2010; Szuścik, 1999, 2006, Stasiakiewicz, 2000; Jolley, Fenn, \& Jones, 2004). The drawings of children and young people have not only been acknowledged for their artistic and aesthetic value, but also for their projective potential which is a source of information on personality (Frydrychowicz, 1984; Fernandez, 2005; Stemplewska-Żakowicz, 2009) ${ }^{1}$, and their psychometric potential which provides information on children's intellectual development (Burt, 1921; Goodenuogh, 1926; Hornowska, \& Paluchowski, 1987). Studies on children's drawings clearly prove that children depict both what they know and what they see. Both knowledge and perception depend on children's personality and intelligence, as well as on the emotions they experience and the attitudes they have. Moreover the content and formal elements of a drawing are subject to the constant change of aesthetic conventions and cultural processes (Strzemiński, 1974; Arnheim, 1978 / 2004; Gombrich, 1981; Francuz, 2013; Didkowska, 2015).

Children are making initial attempts at drawing by the end of the sensori-motor period of intellectual development and translate their experiences and perceptions into socially intelligible signs (Affolter, 1997). This enables children to communicate through forms they have created, experience satisfaction with the representations they have created, and then further enrich, refine and organize these representations into complex hierarchic structures. Not only does this enrich their knowledge of the world and change the way children communicate with other people, but it equally allows them to perfect this instrument of exploring the world that a drawing is, since it is inextricably related to visual thinking. Arnheim (2011, p.157) wrote: drawings, pictures and other intruments not only allow complete ideas to be translated into visual models, but also are of help in elaborating solutions to probems (rysunki, obrazy i inne tym podobne narzędzia służą nie tylko do przekładania gotowych myśli na modele wizualne, lecz także pomagają w procesie wypracowywania rozwiązań problemów). Many authors (e.g. Piaget 1958, Arnheim, 2004 / 2011; Popek, 1978 / 1988; Limont, 1994 / 1996; Stasiakiewicz, 2000; Szuścik 1999 / 2006) emphasize the relationship between drawing activity and developing a sense of subjectivity and identity in children. Being satisfied with their own creative activity is crucial to their development. The artistic status of children's work and of the creative process itself remains an important issue in the discussion on children's creativity (Gardner, 1980; Winner, 1982). The acceptance of children's drawing activity is now growing, chil-

\footnotetext{
${ }^{1}$ A critical analysis of the diagnostic value of various diagnostic procedures based on projection drawing was presented by Stemplewska-Żakowicz (2009).
} 
dren are more likely to be given the right to express themselves freely as individuals, and the creative process itself is now given more credit than before (Lowenfeld, \& Brittain, 1947 / 1977; Karolak, 2005; Józefowski, 1999, 2009).

\section{SELECTED CONCEPTIONS}

The theory of children's drawing activity has been described in a large body of literature. Theoreticians and researchers still argue about the role and status of children's drawing. I believe that drawing activity plays a special role in development, therefore I will discuss classic concepts of artistic development in children aged 3 to 12, focusing on those authors who were interested in the field of visual arts. I will ponder upon the key notions characterizing drawing activity in children aged 3 to 12: ideoplastic art (the period of scheme in drawing development, Szuman, 2008), spontaneous drawing and drawing scheme.

The notion of ideoplastic art was introduced to the Polish literature on children's drawing activity by the prominent psychologist and pedagogue, Szuman. He referred to the theory of Verworn (1908) who christened child's drawing, originating from the outside, ideoplastic art. He contrasted this to physioplastic art, by which he understood drawing that is a faithful copy of nature. Ideoplastic art is modelled on imagination that transforms the model according to its "idea", its scheme; physioplastic art follows the external model (który ochrzcił rysowanie dziecięce, idące z zewnątrz, trafnym mianem ideoplastyki. Przeciwstawia jej fizjoplastykę, przez którą rozumie rysowanie, będące wierną kopią natury. Ideoplastyka wzoruje się na wyobraźni przekształcającej model na jego „ideę”, na jego schemat; fizjoplastyka trzyma się ściśle modelu zewnętrznego) ${ }^{2}$ (Szuman, 2008, p. 12). Szuman pondered upon the idea of drawing scheme, which he considered to be crucial in explaining the notion of ideoplastic art (Szuman, 1927/1990, 2008). Szuman believed that the child uses the apperceptive material to create an idea of objects, which become intrinsic models for drawings, which is why the child does not try to copy nature before the age of 10 . This internal image (intrinsic model) transforms the object into an idea, a scheme for a drawing. A scheme is not a constant; it changes and improves as the child continues to develop. Even though the child draws inspiration from inside, development is stimulated by an external, perceived image that Szuman calls the nature. He emphasizes that the objects which appear in a child's imagination are not a copy of perceived objects, not a facsimile of their real image, but a schematic simplification. When a child is creating a drawing based on imagination, the effect is limited to what is contained within that imagination - an incomplete, simplified image of reality and this is the image expressed by a changing scheme. A child learns to draw with more or less

\footnotetext{
${ }^{2}$ Szuman disagreed with the theory of Verworn who conducted a comparative study on the drawings of children and prehistoric people, which initiated the theory of naive realism. Yet he considered the introduction of terms such as ideoplastic art and physioplastic art to be justified.
} 
realism (physioplastic mode) as the scheme allows an endless multitude of shapes that exist in the real world to be represented. The ultimate stage of scheme development is the type, the perfect scheme, as Szuman calls it. The shape of a scheme is very general, but the shape of a type is realistic and it defines the object in a new, characteristic way. Szuman demonstrates that the stage of development of a drawing type is achieved only by talented children, unless it is interrupted by an outside pictorial convention or a premature introduction to perspective and naturalism (Szuman, 1927 / 1990, 2008). Since a scheme, according to Szuman, is the most interesting phenomenon in the development of children's drawing, he goes further to describe its three stages:

1. Period of doodling, the appearance of a scheme

2. Period of scheme (ideoplastic art)

3. Post-schematic period (development towards physioplastic art).

Szuman attributed figure scheme formation to the post-infant period, ideoplastic art to the period of kindergarten and early primary school (up to the age of 12), and physioplastic art to late primary school. The emergence of the physioplastic mode stage has, according to Szuman, (1927) two sources: the influence of naturalist painting and illustrations that can be found in books, postcards, photographs, drawings, paintings seen at home or at school.

Szuman strongly believes that in our European cultural environment, the patterns provided by adults - painters - are too difficult, naturalistic and too artificial to imitate. The child is not able to use them naturally, without prior instruction, in order to develop in the direction where the drawing activity is leading him spontaneously. A child in our cultural circle is all too soon influenced by illustrations in books, by photographs and the cinematograph. (w naszym europejskim środowisku kulturowym wzory dorosłych - malarzy - są zbyt trudne, naturalistyczne i sztuczne, aby dziecko w sposób naturalny, bez umyślnej nauki, mogło z nich korzystać, rozwijać się w tym kierunku, w jakim się spontanicznie posuwał jego rozwój rysunkowy. Dziecko u nas zbyt rychło dostaje się pod wpływ rycin w książkach, fotografii, kinematografu). (Szuman, 1927 / 1990, p. 69).

Spontaneity should define children's creativity, which is why the teacher and the parent should only assist and advise them. In such drawing activities, Szuman says, a child does not commit any aesthetic mistakes. Drawing on a given topic may well be spontaneous, as long as there is no significant external interference, such as comments suggesting what and how the child should draw. A spontaneous drawing, which should be free from all pressure, is however threatened by the multiplicity of the often contradictory 20th cen- 
tury doctrines and conventions which, as Szuman said in 1927, all influence children, yet none of them can really reach them. External chaos creates internal chaos and it is impossible for a child to maintain his own individual style. (z których każde działa na dziecko, a żaden nie przenika istotnie do jego wnętrza. Na zewnątrz jest chaos i $w$ dziecku powstaje chaos, zatem dziecko nie może utrzymać się przy swoim stylu.) Szuman often referred to the ideas of Luquet. Luquet's book Children's Drawings (Le dessin enfantin), 1927, was published in the same year that Szuman's Children's Art. Psychology of Children's Drawing Creativity (Sztuka dziecka. Psychologia twórczości rysunkowej dziecka), 1927, came out. There is an interesting parallel between their ways of thinking. Both Szuman and Luquet conducted extensive research on children's drawing activity, made detailed descriptions of the subsequent stages of its development, and analyzed the forms and nascence of artworks produced by children and young people, aged 3 to 15. They were both interested in how the psychic life of an individual manifested itself in the form and content of a drawing. Both scholars believed that children depict what they know about an object, and not how they see it. This kind of knowledge accrues due to the intense work of the imagination, and true art, including children's art, is about recreating reality. Yet children do not aim at realism, instead they draw and paint everything they know from their experience and what they can imagine (znają z widzenia $i$ co umieją sobie wyobrazić) (Szuman, 1927/1990). Both Szuman and Luquet used various work methods such as interviews, case studies and quantitative analyses. Based on a longitudinal study of the drawings of his daughter, (Luquet, 1913) and on the observation of other children's drawings, Luquet also attempted to determine stages of development along with their various visual characteristics (Luquet, 1927). He emphasized the ludic character of children's art, the need to manifest one's individual activity, the joy of drawing. He was the one who introduced the notion of an intrinsic model, to which Szuman refers - a model that defines the psychic reality that exists in a child's brain and is the foundation for schematic drawing - both the one existing in the memory and the perceived one. According to Luquet, subsequent stadiums of drawing development in children and young people have a common denominator - realism. These stadiums are: realism of lack - unplanned, functional drawing; realism of coincidence - an attempt at graphic representation of detail, intellectual realism - with the intention of depicting what children know, not what they see, visual realism - an attempt at imitating reality and concern for formal perfection. This is how Luquet opposed the theory of naive realism ${ }^{3}$ and created the founda-

\footnotetext{
${ }^{3}$ This theory juxtaposes the development of child drawing and the development of pictorial art, which is why a drawing by a child aged 3- 6 would correspond to prehistoric art; the drawing of an older child - to Antiquity and the Middle Ages; the drawing of young people - to modern realism.
} 
tion for an intellectual theory which says that children draw what they know, not what they see. This is what Cambier (Wallon et al., 1993) values most in Luquet's theory - introducing the notion of realism, which proves that children, well aware of their abilities, strive to depict reality, and succeed in grasping the meaning of an image. However, she believes that Luquet made one mistake - he identified children's developmental realism with adult visual realism and believed children mimicked the adult model of reality, whereas children's realism derives from a self-centred perspective, which they believe to be absolute and objective. Therefore, in a period when an individual's value system becomes knowledge-based, and technique and virtuosity become the main assets of a drawing, graphic representation is evaluated from the point of view of imperfection, shortcomings and awkwardness (Wallon et al., 1993). Philippe Wallon (1993) says that even though the intrinsic model is the main power and the foundation of a drawing, there also exists an external model, a second power such as photography. According to this author, drawing is the result of these two powers. Both of them can either contribute to the elaboration of a drawing or sabotage it by opposing one another.

American researchers Lowenfeld and Brittain $(1947,1977)$ also tackled the notion of schematism. Their book called Creative and Mental Growth contains a detailed description of the stages of children's artistic development and associates them with how a child perceives reality. Lowenfeld and Brittain believe children and young people of all cultures go through these stages. They also assume that children's artworks reflect all psychic functions: perception, thinking, emotions, imagination and that a drawing can be an indicator of a child's degree of maturity and ability to operate within particular elements of their environment. They singled out the following stages of development: doodling (age 2-4), pre-scheme stage (age 4-7), scheme stage (age 7-9), early realism stage (age 9-12), pseudo-realism stage (age 12-14) - which they divided into: visual and tactile creative types. The visual type is related to visual perception and to the will to represent things as seen in nature, whereas the tactile type is about experiencing the environment and the emotions that arise from that experience. The second type tends to be less sharp in terms of observation, yet is more true to emotions. In his subsequent articles, Lowenfeld (1947) adds that more people tend to represent the visual or mixed type because visual stimuli prevail in our culture. The last phase of artistic creativity development is the artistic crisis during adolescence (age 14-17). Lowenfeld says that attempts to create defined shapes result directly from the experience of doodling. During the pre-scheme period a child starts to look for symbolic forms. Both Lowenfeld and Brittain say that every child has an individual way of representing reality, specific schemes which are then modi- 
fied and completed with new detail resulting from accrued experience and emotions. Following role-models that can be found in picture books, drawings of other children, stimulation and comments coming from parents and teachers, also contributes to construing schemes. Lowenfeld, Szuman and Luquet all believe that the role of a scheme becomes apparent only when a drawing depiction is a result of a thorough individual search, inextricably related to a child's personality. As far as the notion of realism is concerned, it does not need to be a photographic reproduction of nature, but a child's effort to depict an object as a visual concept including elements of experience and information, not solely visual.

Arnheim $(2004,2011)$ had yet a different view of the development of drawing activity. He founded his conception on gestalt psychology. The followers of this school believe that drawing consists of two basic processes: perception (visual) and expression (motor). This is why, according to Arnheim, the drawing process depends on perception and behaviour, which are brain-determined. This view is a polemic with the idea that children only draw what they know, and not what they see. Arnheim pointed out that in most cases creating images does not rely on what one can notice while drawing. The person who is drawing is making a synthesis of previous observations of objects of a certain category: horses, trees, human figures. This process can be called knowledge-based drawing; but it is not the kind of knowledge that opposes visual perception. Children do draw what they know, but it is a knowledge based on a synthesis of previous visual experiences. A young brain sees things as they are - what they look, sound, move and smell like. Arnheim (2011, p. 302) points towards a visual kind of thinking that requires more than just creating and attributing meaning to notions (wymaga czegoś więcej niż jedynie umiejętności tworzenia pojęć i nadawania im znaczeń). He emphasizes that in order to create a drawing, one has to think. He equally disagrees with the theory of naive realism - a figure drawn by a child is not more schematic than one drawn by Rubens. Only less diversified. We believe Dürer's naturalist sketches of arms, faces and bird wings to be works of art only because these few lines and shapes form well ordered, yet complex patterns which interpret the subject.

Arnheim follows the ideas of gestalt psychology and proves that perception does not depart from detail, which is then intellectually transformed into abstraction, but from general traits. Before we notice the individual character of one particular dog, we grasp what defines all dogs. First artistic representations are based on naive observation and focus on general, simple aspects of a structure. Children draw objects and shapes in a simple, general way because this is how they see them. Although one should bear in mind that children see more than they draw, but they depict only as much as they find necessary 
to convey what they find that makes an image. Whether or not the depiction resembles the object depends on the criteria adopted by the child, and what the drawing is made for. As the children's cognitive development progresses, they move to another level and create more complex patterns. The first well-organized shape to emerge from doodling is a circle. According to gestalt theory this is because the circle is the simplest shape that can be conveyed through the pictorial medium - it is characterized by centric symmetry in all directions. Before children master other shapes, they use the circle to represent each element of reality, including objects that have different shapes, such as the cutting blade of a circular saw. This shape is later modified to form more angular forms. It is not until children can operate a variety of shapes that the circle starts to signify roundness. Other formal elements that children introduce into their work undergo a similar evolution. The line, initially only straight, stands for all oblong shapes. Only when the line is completed with curves, do children also start to differentiate these two shapes. The same goes for angles, $90^{\circ}$ is the basic one, the first one to appear and initially represents all pictorial relations of such a type. Similarly, at first children cannot tell the difference in the size of different objects - a house, a tree or a human figure have the same size. Then intentional use of size appears which in turn morphs into differentiating realistic relations of size. This course of drawing development - from general to more complex shapes is believed to be a universal pattern that appears and develops autonomously, regardless of culture and education. Accomplishing any painting requires the use of depiction notions that are an equivalent of visual notions one wants to depict, and are expressed in the work of a pencil, brush or chisel.

Arnheim's book, particularly the chapter on the development of drawing activity in children and young people, inspired Gombrich (1981). After reading this comprehensive chapter, he decided he no longer needed to tackle this topic in his own work that he summarized in a book entitled Art and Illusion. A Study in the Psychology of Pictorial Representation. Instead, Gombrich discusses the works of great painters seen against a historic background which explains their intentions. Every work of art, he says, is born out of imitation or denial of what came before it. Gombrich (1981) points out that art can take different meanings in different times and places. Most people like to see in paintings what they would like to see in reality. They wish to admire the artist's talent in depicting things they see and have a taste for paintings that look realistic. We have this strange habit, says Gombrich, of assuming that nature should always look the way we are used to seeing it. Painting is an action and the artists see what they paint, rather than what they see. There is no such thing as unbiased naturalism. A visual artist, no less than a writer, 
needs a lexical resource to imitate reality. To describe the world with pictures, an artist needs an elaborate system of schemes. Gombrich, like Arnheim, points out that there is no major difference between the simplified drawings of children and much more elaborate systems of naturalistic images. However, it is not because the scheme is more complex, but because every art is born in the human brain and is an expression of an experience of the world, rather than of its perception. We call it conceptual because an image can be recognized by its style. Gombrich points out that experience cannot be neatly separated from knowledge. The starting point for visual representation is not knowledge but supposition driven by habit and tradition.

In Poland, a similar theory was elaborated by Strzeminski, (1974) whose lectures on art history were published in a book called Theory of Vision (Teoria widzenia). The author accentuates the socio-historic character of perception, which changes throughout history, depending on knowledge, views and current value systems. Strzeminski (1974) says that thought and vision influence one another. He describes two evolutions of vision. One is the evolution of our ocular apparatus, the development of the eye, and the other is the development of the ability to use vision. Thought and vision develop through mutual influence.

Visual awareness accrues in the course of history and we cannot assume, like idealists do, that there exists one timeless, non-historic image of reality, founded on the same visual rights that govern every normal human being's perception. For it is not biology that determines vision, but the cooperation of thought and vision - a historically determined development of visual awareness. Not an abstract void of "normal" vision, but a historically determined, growing body of visual awareness. What makes the process of seeing is not what the eye catches mechanically, but how much of our own perception we become aware of. The increase in visual awareness is a reflection of human development. (Stojąc na gruncie historycznego narastania świadomości wzrokowej nie możemy uznać, jak to czynią idealiści, że istnieje jakiś jeden pozaczasowy, pozahistoryczny obraz rzeczywistości, zbudowany na zasadzie tych samych praw wzrokowych, podług których oko każdego normalnego człowieka widzi tę rzeczywistość. W widzeniu rzeczywistości decyduje nie biologiczny odbiór doznań wzrokowych, lecz współpraca widzenia i myśli - historycznie uwarunkowany rozwój świadomości widzenia. Nie abstrakcyjna próżnia widzenia „normalnego”, lecz historyczny, narastający konkret świadomości wzrokowej. W procesie widzenia nie jest ważne, co mechanicznie chwyta oko, lecz to, co człowiek uświadamia sobie ze swego widzenia. Wzrost świadomości wzrokowej jest odbiciem procesu rozwoju ludzkiego.) (Strzemiński, 1974, p. 14, 15). 


\section{CONCLUSION}

Despite certain differences in their ideas, all authors agree that children's drawing activity must not be rushed or readjusted, and that children should not be made to change the way they draw. A teacher or a parent should not show tricks or shortcuts leading to an easy way of achieving expected visual effects. Children should not be encouraged to draw like an adult, nor helped-out in drawing. Stefan Szuman points out that children's drawings should be weighed against the average results of their peers.

We want small children to speak and act like children, not like adults; this is why we value drawings that reflect the children's age, as well as their style and character. Children's drawings are pretty when they are simple and honest, not fake and "bumptious". (Chcemy, aby małe dzieci mówiły po dziecięcemu, postępowały jak dzieci, a nie jak dorośli; dlatego też cenimy rysunki charakterystyczne dla danego wieku oraz odpowiadające jego stylowi i wyrazowi. Rysunki dzieci są między innymi wówczas ładne, gdy mają prosty, szczery I bezpośredni wyraz, a nieładne, gdy są sztuczne i „przemądrzałe”.) (Szuman, 2008, p. 17).

Szuman also believes that children's drawings should not imitate the art of adults since drawing ability can develop freely only in the style that is appropriate to the child's current stage of development. Arnheim compares children's creativity to climbing stairs:

when climbing the stairs one has to take one step in order to take another; the first step is not an obstacle, but a prerequisite for making another. Similarly, the first depictions do not tie one down, but are the necessary forms of one's own early concepts. [...] As the brain continues to develop and moves on to higher levels, these patterns become more elaborate. These processes are parallel and influence one another (kiedy ktoś wspina się na schody, musi pokonać pierwszy stopień, żeby wejść na drugi; pierwszy stopień nie jest jednak przeszkodą, tylko wstępnym warunkiem osiągnięcia drugiego. Podobnie pierwsze pojęcia przedstawieniowe nie są więzami, ale nieodzownymi formami wczesnych koncepcji. [...] W miarę jak umysł rozwija się $i$ wkracza na poziomy wyższe wzory, które tworzy, stają się coraz bardziej złożone. Procesy te idą w parze i nieustannie stymulują się nawzajem.) (Arnheim, 2004, p. 198).

Lowenfeld and Brittain also share a strong view about adults imposing drawing patterns on children. They even say that if teaching visual arts is to consist of these kinds of actions, children would be better-off without any art classes. Learning to imitate hinders spontaneous creative expression and emotional development, since any divergence from a preconceived pattern may be considered to be a mistake, which constrains the development of 
children's abilities. It also leads to applying criteria that are appropriate to the art of adults, which may frustrate children's needs for creativity (Lowenfeld, Brittain, 1977).

In the contemporary world we live in, reality yet rub on the imaginary, which makes us dive deeper and deeper into the virtual world which is filled with both images deriving from reality and created or manipulated images. In this kind of world artists have long since ceased to try to express themselves and the surrounding world in the form of a faithful depiction of reality, and are now searching for new meanings and ways to express such a complicated mode of human life and their own existence.

In spite of these changes, it is a common practice in education to judge children's drawing abilities by how they can imitate Pokémon images, fill the pages of colouring books or try to "correctly" depict e.g. a horse. Maybe now, more than ever, we expect children's artwork to fulfill the aesthetic needs of adults, since we have long forgotten what the role of drawing in development really is. Therefore it seems justified to recall notions which I believe remain crucial in understanding the drawing activity of children aged 3 to 12 .

\section{REFERENCES}

Affolter, F. (1997). Spostrzeganie, rzeczywistość, język (Perception, Reality, Language). Warszawa: WSiP.

Arnheim, R. (2004). Sztuka i percepcja wzrokowa (Art and Visual Perception). Gdańsk: Wydawnictwo słowo/obraz terytoria.

Arnheim, R. (2011). Myślenie wzrokowe (Visual Thinking). Gdańsk: Wydawnictwo słowo/ obraz terytoria.

Burt, C. (1921). Mental and Scholastic Tests. London: P.S. King and Son.

Cooke, E. (1885). Art. Teaching and Child Nature. London Journal of Education, 7 (197), 462-465.

Didkowska, B. (2015). Rysunek dziecka w wieku od 7 do 12 lat a język wizualny nowych mediów (Drawings of Children aged 7-12 and the Visual Language of New Media). Toruń: Wydawnictwo Naukowe UMK.

Fernandez, L. ( 2005). Le test de l'arbre (Tree Test). Paris: Editions in Pess.

Francuz, P. ( 2013). IMAGIA. W kierunku neurokogniwistycznej teorii obrazu (Towards a Neurocognitivistic Image Theory). Lublin: Wydawnictwo KUL.

Frydrychowicz, A. (1984). Rysunek rodziny. Projekcyjna metoda badania stosunków rodzinnych (A Family Drawing. Projective Techniques in Evaluating Family Relations). Poznań: Wydawnictwo Naukowe UAM.

Gaitskell, Ch.D., Hurwitz, A. (1975). Children and Their Art. New York - Chicago-San Francisco- Atlanta: Harcourt Brace Jovanovich, INC. 
Gardner, H. (1980). Artful scribbles. The Significance of Children's Drawings. New York: Basic Books.

Gombrich, E. (1981). Sztuka i złudzenie. Warszawa: PIW.

Goodenuogh, F. (1926). Measurement of Intelligence by Drawings. Yonkers-on-Hudson. Grudzińska, A. (1013). Rysunki dzieci polskich (Drawings of Polish Children). „Kształt $i$ Barwa”, z. 4.

Hornowska, E., Paluchowski, W.J., (1987). Rysunek postaci ludzkiej GoodenoughHarrisa (Drawings of Human Figures by Goodenough-Harris). Poznań: Wydawnictwo Naukowe UAM.

Hornowski, B. (1982). Badania nad rozwojem psychicznym dzieci i młodzieży na podstawie rysunku postaci ludzkiej (Studies on Psychological Development of Children and Young People Based on Representations of the Human Figure in Drawings). Wroclaw: Ossolineum.

Jolley, R.P., Fenn, K., Jones, L. (2004). The Development of Children's Expressive Drawing. British Journal of Developmental Psychology, 22, 545-567.

Józefowski, E. (1999). Książka o książkach (A Book on Books). Zielona Góra: Wydawnictwo WSP TK.

Józefowski, E. (2009). Edukacja artystyczna w działaniach warsztatowych (Art Education in Workshop Activities). Łódź: Wydawnictwo Akademii Humanistyczno-Ekonomicznej $w$ Łodzi.

Karolak, W. (2005). Warsztaty twórcze - warsztaty artystyczne (Creative Workshops - Art Workshops). Kielce: Wydawnictwo “Jedność”.

Kellogg, R. (1970). Analyzing Children's Art. Palo Alto. National Press Books

Kościelecki, S. (1975). Współczesna koncepcja wychowania plastycznego (Contemporary Conceptions of Artistic Education). Warszawa: PWN.

Lam, W. (1960). Sztuka dziecka i jej naturalny rozwój (Children's Art and its Natural Development). Warszawa: NK.

Lam, W. (1967). Malarstwo dzieci w świetle współczesnych poglądów (Contemporary Views on Children's Paintings). Warszawa: NK.

Limont, W. (2010). Uczeń zdolny. Jak go rozpoznać i jak z nim pracować (Talented Students. How to Recognize and Work with Them). Gdańsk: Gdańskie Wydawnictwo Psychologiczne.

Limont, W. (1994). Synektyka a zdolności twórcze (Synectics and Creative Abilities). Toruń: Wydawnictwo Naukowe UMK.

Limont, W. (1996). Analiza wybranych mechanizmów wyobraźni twórczej (Analysis of Selected Mechanisms of Creative Imagination). Toruń: Wydawnictwo Naukowe UMK. 
Lowenfeld, V., Brittain, W. L. (1977). Twórczość a rozwój umysłowy dziecka (Creativity and Mental Development of Children). Warszawa: PWN.

Lownefeld, V., Brittain, W.L. (1947). Creative and Mental Growth. New York: MacMillan.

Luquet, G.H. (1913). Les dessins d' un enfant (Children's Drawings). Paris: Alcan.

Luquet, G.H. (1927). Dessin enfantain (Children's Drawings). Paris: Alcan.

Marciniak, T. (1976). Problemy wychowania plastycznego (Problems of Artistic Education). Warszawa: NK.

Malraux, A. (1985). Przemiany bogów (The Metamorphosis of the Gods). t.3. Warszawa: Krajowa Agencja Wydawnicza.

Popek, S. (1978). Analiza psychologiczna twórczości plastycznej dzieci i młodzieży (Analysis of Artistic Activity of Children and Young People). Warszawa: WSiP.

Popek, S. (2010). Psychologia twórczości plastycznej (Psychology of Artistic Creativity). Kraków: Impuls.

Popek, S. (Eds.) (1988). Aktywność twórcza dzieci i młodzieży (Artistic Activity of Children and Young People). Warszawa: WSiP.

Ricci, C. (1887). L'arte dei Balbini (Art of Children). Bologna: Armando Editore.

Stasiakiewicz, M. (2000). Prototypowy obraz świata w rysunku dziecka (Prototypical Image of the World in Children's Drawings). Poznań: Edytor.

Stemplewska-Żakowicz, K. (2009). Diagnoza psychologiczna (Psychological Diagnosis). Gdańsk: GWP.

Strzemiński, W. (1974). Teoria widzenia (Theory of Vision). Kraków: WL.

Szuman, S. (1927). Sztuka dziecka. Psychologia twórczości rysunkowej dziecka (Children's Art. Psychology of Children's Artistic Activity). Warszawa: Książnica-Atlas. Szuman, S. (1969). O sztuce $i$ wychowaniu estetycznym (On Art and Artistic Education). Warszawa: PZWS.

Szuman, S. (1990). Sztuka dziecka. Psychologia twórczości rysunkowej dziecka (Children's Art. Psychology of Children's Drawing Activity). Warszawa: WSiP.

Szuman, S. (2008). Wybór pism estetycznych (Selected Writings on Aesthetics). Kraków: Wydawnictwo Universitas.

Szuścik, U. (1999). Kształtowanie percepcji wzrokowej jako stymulator działań dziecka (Developing Visual Perception as a Way of Stimulating Children's Activities). Cieszyn: UŚ Filia w Cieszynie.

Szuścik, U. (2006). Znak werbalny a znak plastyczny w twórczości rysunkowej dziecka (Verbal and Visual Signs in Children's Artistic Activity). Katowice: Wydawnictwo Uniwersytetu Śląskiego. 
Trojanowska, A. (1975). Dziecko i twórczość (A Child and Creativity). Wrocław: Ossolineum. Trojanowska, A. (1988). Dziecko i plastyka (A Child and Artistic Creativity). Warszawa: WSiP. Verworn, M. (1908). Zur Psychologie der primitiven Kunst (On Psychology of Art Brut). Jena: Gustaw Fischer.

Wallon, P., Cambier, A., \& Engelhard, D. (1993). Rysunek dziecka (Children's Drawings). Warszawa: WSiP.

Winner, E. (1982). Invented Worlds: the Psychology of the Arts. Cambridge: Harvard University Press.

Corresponding author at: Bernadeta Didkowska, Department of Art Education, Nicolaus Copernicus University, 4 Sienkiewicza St., 87-100 Toruń, Poland.

E-mail: bedid@poczta.onet.pl 